\title{
Evlilik Neyi Değiştirir? Kadın Girişimciler Üzerine Karşılaştırmalı Bir Uygulama*
}

\author{
What Does Marriage Change? A Comparative Survey on Women Entrepreneurs \\ Esra Sena Türko ${ }^{a}{ }^{* *}$, Duygu Tulan ${ }^{\mathrm{b}}$ \\ ${ }^{a}$ Dr. Öğr. Üyesi, Erzurum Teknik Üniversitesi, İktisadi ve İdari Bilimler Fakültesi, İktisat Bölümü, 25100, Erzurum/Türkiye. \\ ORCID: 0000-0002-9102-6120

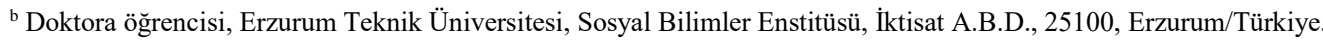 \\ ORCID: 0000-0002-0230-3334
}

\section{MAKALE BİLGISI}

\section{Makale Geçmişi:}

Başvuru tarihi: 20 Eylül 2018

Düzeltme tarihi: 16 Ekim 2018

Kabul tarihi: 05 Kasım 2018

\section{Anahtar Kelimeler:}

Kadın Girişimciliği

Kadın Girişimciler

Evlilik

Medeni Durum

Erzurum

\section{ARTICLE INFO}

\section{Article history:}

Received 20 September 2018

Received in revised form 16 October 2018

Accepted 05 November 2018

\section{Keywords:}

Women Entrepreneurship,

Women Entrepreneurs ,

Marriage,

Marital Status,

Erzurum

\section{ÖZ}

$\mathrm{Bu}$ araştırmanın amacı, evli ve bekâr kadın girişimciler arasında çeşitli değişkenler açısından farklılık bulunma durumunu araştırmaktır. Erzurum il merkezinde çeşitli sektörlerde faaliyet gösteren 200 kadın girişimciye anket uygulanmıştır. Veri seti Tek Örneklem Kolmogorov-Smirnov testi ve parametrik olmayan Mann-Whitney U testi kullanılarak analiz edilmiştir. Analiz sonuçları kadın girişimciler arasında 32 değişkenin sadece 4 tanesinde evli olma durumuna göre farklılık bulunduğunu göstermektedir. Evli girişimciler, bekâr girişimcilere kıyasla daha düşük eğitim seviyesine ve daha yüksek yaș ortalamasına sahiptir, daha çok çalışan istihdam etmektedir ve satış fiyatlarını belirlemede daha az zorlandığını ifade etmiştir. Diğer yandan evli ve bekâr kadın girişimciler arasında 28 değişkende istatistiksel olarak anlamlı bir farklılık bulunmadığı tespit edilmiştir. Evli ve bekâr kadın girişimciler işletmeyi kurarken ve yönetirken benzer düzeylerde sorun yaşamıştır.

\section{A B S T R AC T}

The aim of this research is to investigate the differences between married and single women entrepreneurs. A questionnaire is applied to 200 women entrepreneurs operating in various sectors in Erzurum city center. Data set is analyzed by using One Sample Kolmogorov-Smirnov test and non-parametric Mann-Whitney U test. Analysis results indicate that mean ranks for two groups differ significantly from each other only in 4 variables among 32 variables, according to marital status. Compared to single entrepreneurs, married entrepreneurs seem to have lower education level and higher average of age; employ more employees and have expressed less difficulty in determining sales prices. On the other hand, two groups do not significantly differ from each other in 28 variables. Married and single women entrepreneurs encountered problems in the start-up phase in business management at similar levels.

\section{Giriş}

Kadın girişimciliği, istihdam ve kadın istihdamının özel bir alanı olarak kabul görmüş ve bu konuya olan ilgi, hem gelişmiş hem de gelişmekte olan ülkelerde giderek artış göstermiştir (Kutukız ve Özden, 2018: 353; Najimudinova, 2015: 8). Kadınların çalışma hayatında aktif rol oynamaları için farkındalık ve kapasite geliştirme yönünde çalışmalar yapılmış bu çalışmalar ile kadınların girişimcilik faaliyetlerinde bulunmaları teşvik edilmiştir (Boyacıoğlu, 2014: 84). Ancak yine de kadın girişimciler cinsiyetleri baz alınarak iş kurma ve mevcut işlerini yürütmede çeşitli engeller ile karşılaşmakta; biyolojik ve fizyolojik özelliklerine bağlı olarak, kendilerine atfedilen rolleri ile

* Bu çalışma, 7-8 Eylül 2018 tarihlerinde Aydın/Didim'de düzenlenen IV. Uluslararası Kafkasya-Orta Asya Dış Ticaret ve Lojistik Kongresi'nde bildiri olarak sunulmuştur.

** Sorumlu yazar/Corresponding author.

e-posta: esturko@erzurum.edu.tr 
ilgili sorunlar yaşamaktadır (Akgül Koç ve Siklon, 2009: 266). Hatta toplumsal cinsiyet temelli iş bölümünce kadına verilen eşlik/annelik görevlerini içselleştirmişleriyle kadınlar, işgücü piyasasından geçici ya da sürekli ayrılmaktadır. Kadını toplumda denetlenen konumuna indirgeyen ataerkil yapının getirdiği hiyerarşik bu düzen, kadının işgücü piyasasına katılımında belirleyici rol oynamaktadır (Özçatal, 2009: 52). Geleneksel olarak belirlenmiş cinsiyet rollerinin bu şekilde benimsenmesi ise kadınların erkeklere bağımlılıklarının ölçüsünü ifade etmektedir. Bazı kadınlar bu durumdan rahatsızlık duyarken bazıları bu durumu normal ve doğal olarak karşılamaktadır. $\mathrm{Bu}$ bağımlılık nedeniyle kadınların önemli bir bölümü için hayattaki en önemli amaç iyi bir anne ve eş olmaktır (Goffee ve Scase, 1992: 13).

Evlilik davranışları etkiler, günlük rutinleri ve alışkanlıkları değiştirir (Erdoğan, 2017:4-10). Evlilik evlenen kadın ve erkeklere gelirlerinde artış, ücretlerinde göreceli farklılık gibi çeşitli kazanımlar getirir (Becker, 1973: 813). Peki evlilik kadın girişimciler açısından neyi değiştirir? Kadınların iş kurma süreçlerinde ve işlerini yönetirken karşılaştıkları sorunları azaltır mı? Evli kadınlar kalıpyargıların söylediği gibi ev sorumluluklarını aksatır mı, iş yüklerinin artması nedeniyle işletme yönetiminde başarısız olur mu? Evli kadınlar kendilerine biçilen roller ve davranış kalıpları nedeniyle daha mı çok baskı ve ayrımcılığa maruz kalır? Tüm bu sorular kadın girişimciliği araştırmalarına özeldir. Örnekleminin erkeklerden oluştuğu bir araştırmada medeni durum değişkeni açısından analiz yapıldığında bu ve benzeri soruların cevapları aranmaz. $\mathrm{Bu}$ durum toplumsal cinsiyet rollerinden ve cinsiyet rolleri konusundaki kalıpyargılardan kaynaklanmaktadır.

Girişimcilik araştırmalarında demografik faktörlerden medeni durum değişkeninin analize dahil edilmesi araştırmanın odak noktasına göre- evli ve bekâr girişimciler arasında çeşitli konularda (örneğin, motivasyon kaynaklarını ve davranış kalıplarını değerlendirme konusunda) sonuçlar vermektedir. Risk alma düzeyi konusunda medeni durum açısından bir farklılık ortaya çıktığı zaman evliliğin girişimciye getirdiği sorumluluk duygusu vb. gerekçelerle bu farklılığın ortaya çıktığı yönünde değerlendirmeler yapılmaktadır. Kadın girişimciler söz konusu olduğu zaman ise, medeni durum değişkeni, tüm bu değerlendirme ve yorumlara ek/farklı olarak, kadının toplumsal cinsiyet rolleri nedeniyle maruz kaldığı baskı ve engellemeler ve mücadele ettiği kalıpyargılara ilişkin sonuçlar vermektedir.

Yakın zamanda yapılmış uygulamalı çalışmalar, Türkiye'de kadın girişimcilerin düşünüldüğü kadar çok sorun yaşamadıklarını (Türko, 2016b: 56; Uluköy ve Bayraktaroğlu, 2014) ve çatışma odaklarını stratejiler geliştirerek çözdüklerini göstermektedir (Batı ve İnel, 2015). Oysa kadınların girişimci olmaları durumunda başarısız olacakları ve bask1 görecekleri konusunda kuvvetli kalıpyargılar bulunmaktadır. Uygulamalı çalışmaların kalıpyargıları temelsiz bırakan ve kadın girişimciliğini teşvik eden bu olumlu sonuçlarının, toplumla daha fazla paylaşılması, kalıpyargıların ortadan kaldırılmasına katkıda bulunacaktır (Tulan ve Türko, 2018: 303).

Erzurum'da kadın girişimcilere uygulanan bir saha araştırmasında, kadınların medeni durumlarının kaydedilmesi konusunda araştırmacıların sorun yaşadığ ifade edilmektedir. Kadın girişimcilerin sözlü olarak boşanmış/boşanma sürecinde olduklarını ifade etmelerine rağmen anket formuna evli olarak kaydedilmek istedikleri görülmüştür. Ayrıca çocuk sayısı sorusunun medeni durumdan önce sorulmasını sorun eden ve olumsuz tepki veren girişimciler olmuştur. Eşleri ile birlikte çalışan kadınların sorulara cevap verirken, göz teması ile veya sözlü olarak eşlerinden onay alma ihtiyacı hissettikleri gözlenmiştir. Araştırmada, kadın girişimcilerin hissettikleri toplumsal baskı, karar verme süreçlerine katılım durumları gibi hususların derinlemesine araştırılması önerilmekte, ataerkil toplumsal yapının geçerli olduğu bölgelerde girişimci olmaya karar verecek kadınların karşılaşacağı toplumsal sorunların daha iyi anlaşılmasına katkıda bulunacağı ifade edilmektedir (Tulan ve Türko, 2018: 302).

Bu noktadan hareketle çalışmanın amacı, evli ve bekâr kadın girişimciler arasında çeşitli değişkenler açısından farklılık bulunma durumunu araştırmaktır. Bu amaca yönelik olarak Erzurum il merkezinde çeşitli sektörlerde faaliyet gösteren 200 kadın girişimciye saha araştırması uygulanmıştır. Araştırmanın ataerkil toplumsal yapı nedeniyle güçlü kalıpyargıların bulunduğu düşünülen bir bölgede Erzurum'da gerçekleştirilmesi tercih edilmiştir. Bölgede spesifik olarak kadın girişimcileri konu alan araştırma sayısı çok kısıtlıdır. Uygulama sonuçlarının bölgede kadın girişimciliğinin desteklenmesi konusunda tasarlanacak programlara katkıda bulunması beklenmektedir.

Türkiye'de spesifik olarak evli ve bekâr kadın girişimciler arasındaki farklılıklar üzerine odaklanan çalışma bulunmamaktadır. Ancak girişimcilik ve kadın girişimciliği konusunda gerçekleştirilen saha araştırması içeren çalışmalarda medeni durum bir değişken olarak analize dahil edilmiştir. Bu çalışmaların pek çoğu girişimci veya girişimci adaylarından oluşan örnekleme sahipken, kısıtlı sayıda çalışma kadın girişimciler üzerine uygulanmıştır. Araştırma sonuçlarının medeni durum değişkeninin kullanıldığ girişimcilere odaklanan başka çalışmalara öncülük etmesi ve bu konudaki kalıpyargıların ortadan kaldırılmasına katkıda bulunması beklenmektedir.

\section{Girişimcilik Araştırmalarında Evlilik}

Çok farklı kültürel yapıya sahip ülkelerde girişimcilere uygulanan saha araştırmaları evlilik ile girişimci faaliyeti arasında pozitif bir ilişki ortaya koymaktadır: Norveç'te (Berglann vd., 2010: 17), Hindistan'da (Bose, 2012: 144; Baruah, 2010: 103; Tamizharasi ve Panchanatham, 2010: 215), Nijerya'da (Olowa ve Olowa, 2015: 31; Aderemi, 2008), Kenya'da (Peter ve Munyithya, 2015: 26-27) ve ABD'de (Moutray, 2007) evli bireyler girişimci olmaya daha meyillidir.

Girişimcilerin yanı sıra potansiyel girişimcilerin örneklem içinde yer aldığ 1 veya örneklemin sadece potansiyel girişimciler olarak nitelendirilebilecek gruplardan (öğrenci gibi) oluşması durumunda bulgular değişiklik göstermektedir. İran'da üniversite öğrencilerine uygulanan bir saha araştırmasında girişimci ruhu ile medeni durum arasında anlamlı bir ilişki bulanamamıştır (Aghajani ve Abbasgholipour, 2012: 63). Nijerya'da demografik faktörlerin girişimci kültürü üzerindeki etkisini araştıran bir çalışmada üniversite öğrencilerinin medeni duruma göre aralarında farklılık bulunduğu, bekâr öğrencilerin daha yüksek düzeyde girişimci özellikler gösterme eğiliminde 
olduğu kaydedilmiştir (Adewele, 2016: 10). Benzer şekilde ABD'de gerçekleştirilen bir araştırmada dinamik panel veri analizi kullanılmış, medeni durumun girişimciliğin bir kariyer tercihi olarak benimsenmesi üzerinde anlamlı bir etkisi olmadığı sonucuna ulaşılmıştır. Örneklemin sadece \%25'i kendi işinin sahibidir (Thompson vd., 2013: 8-9).

Evlilik girişimcilere ne tür avantajlar sağlıyor olabilir? Evli girişimcilerin sağladıkları sosyal, finansal ve psikolojik destek sayesinde bekâr, boşanmış veya dul girişimcilerden daha çok çalıştığ 1 ve işletme yönetiminde daha iyi performans sergilediğini kaydeden çalışmalar bulunmaktadır (Reynolds, 1999; Fielden vd., 2000; Adegbite vd., 2006; Aderemi, 2008: 169).

Norveç'te gerçekleştirilen bir saha araştırmasında evli olma durumunun kadın ve erkeklerin girişimci eğilimi ile yüksek derecede ilişkili olduğu kaydedilmiştir. Bu ilişkinin muhtemel sebepleri şöyle sıralanmışırı: i) girişimciliğin riskli dönemleri için gelir sahibi bir eş, sigorta sağlar ii) kendi işinde çalışan bir eş, önemli bir bilgi kaynağ 1 ve ağ sunar. iii) işsiz bir eş, ucuz (vergisiz) ve güvenilir iş gücü sunar iv) girişimci insanlar girişimci olmayanlara göre daha çok evliliğe meyillidir (Berglann vd., 2010: 17).

Kenya'da girişimcilere uygulanan bir saha araştırmasında medeni durumun girişimci başarısını olumlu yönde etkilediği sonucuna ulaşılmıştır (Peter ve Munyithya, 2015: 26-27). Nijerya'da evliliğin tarımsal işletme geliştirmeye yardımcı olduğu sonucuna ulaşmış ve sebebini örneklemin büyük bir çoğunluğunun evli olmasına bağlamıştır (Olowa ve Olowa, 2015: 31).

Başarılı bir kadın girişimci evli mi olmalıdır? Evliliğin kadına getirdiği sorumluluklar ve toplumsal roller, kültürlere göre ve sosyo-ekonomik düzeye göre farklılık gösterebilir. Ayrıca hâlihazırda girişimci olan kadınların tutumları ile girişimci adayı kadınların tutumları arasında da farklılık bulunması beklenebilir.

Bangladeş'te girişimci ve girişimci adayı kadınlara yapılan bir saha araştırması sonuçları kadınların algı düzeyleri ile ilgili farklılıkları ortaya koymaktadır. Örneklem içinde yer alan girişim sahibi kadınların tamamına yakını başarıı ı girişimcilerin evli olması gerektiği yönünde görüş bildirmiştir. Yazarlar, eşlerin girişimcilik mücadelesinde kadınlara yardımcı olacağı düşüncesiyle bu yönde görüş bildirdiklerini belirtmektedir. Diğer yandan örneklem içinde küçük bir yer tutmakla birlikte girişimci adayı kadınların tamamı başarılı bir girişimcinin bekâr olması gerektiğini belirtmiştir. $\mathrm{Bu}$ düşüncenin altında, bekâr kadınların bağımsız bir şekilde çalışabilecekleri ve eşlerinden kaynaklanacak sorunlarla karşılaşmayacakları öngörüsü bulunmaktadır. Girişim sahibi kadınlar ile girişimci adayı kadınlar arasında istatistiksel olarak anlamlı bir farklılık bulunduğu kaydedilmiştir (Latif, Begum ve Lubna, 2015: 107-108).

Eşler kadınların girişimci faaliyetine engel mi olur? Güçlü ataerkil toplumsal yapının geçerli olduğu toplumlarda bu sorunun cevabının eşlerin kadınlara girişimcilik faaliyetlerinde engel olacağı yönünde olduğu düşünülebilir. Zira kadının çalışma hayatına dâhil olmasıyla ilgili güçlü kalıpyargılar bulunmaktadır. Ancak uygulamalı çalışmalar ve kadın girişimciliği konusundaki yazın aksini söylemektedir.
Eşler genellikle önemli problemlerini birbirleriyle tartışırlar. Eşler arası mesleki tecrübelerin ve iş firsatları konusunda bilginin paylaşımı gibi hususlar, eşler arasında doğrudan bilgi aktarımının gerçekleşmesini sağlar. Ayrıca eşlerden birinin sahip olduğu networkten, tecrübeleriyle edindiği bilgiden, motivasyonundan ve becerilerinden diğer eş doğrudan faydalanmaktadır (Liao ve Stevens, 1994; Bernardi, 1999; Özcan, 2011: 6-7). Dolayısıyla kadın girişimci için eşi, yeni bilgiye erişimini sağlayan önemli bir kaynaktır.

Hindistan'da kabile sisteminin geçerli olduğu bir bölgede evli kadın girişimciler için eşlerinin ana rehberlik kaynağ 1 olduğu ifade edilmektedir. Genç bekâr girişimciler için ise ebeveynleri girişimci kariyerlerine rehberlik etmektedir (Baruah, 2010: 103). Kenya'da kadınlar tarafindan işletilen küçük ölçekli işletmelerde, kadınların eşlerinden destek aldıkları kaydedilmiştir (Orwa, Tiagha ve Waiguchu, 2014: 210).

Kadın girişimcinin evli olması durumunda ev işlerini ve çocukların bakımını aksatacağı veya ev işlerinin işletme yönetimini aksatacağı ve kadını başarısızlığa sürükleyeceği yönünde bir kalıpyargı bulunmaktadır (Türko, 2016b). Toplumsal cinsiyet rollerinden beslenen bu kalipyarg 1 hakkında uygulamalı çalışmalar kadınların çatışma odaklarını stratejiler geliştirerek çözdüklerini göstermektedir (Batı ve İnel, 2015).

Kadın girişimciler toplumun kendilerine yüklemiş olduğu roller ile girişimciliğin gerektirdiği roller arasında çatışma yaşamaktadır (Şahin, 2006). Yalova'da kadın girişimcilerin iş-aile ve aile-iş odaklı çatışma yaşama durumları; zaman, gerginlik, davranış ve enerji boyutlarıyla irdelenmiştir. Çalışma sonuçlarına göre yeni girişim sahibi olan kadınlar daha fazla iş-aile çatışması yaşamaktadır. Evde ve işyerinde profesyonel yardım alarak, sorumluluklarını paylaşan kadın girişimciler ise daha az çatışma yaşamaktadır. Rol paylaşımı yapan kadınların her açıdan daha sağlıklı oldukları ve iş-aile dengesini daha iyi kurdukları; yenilikçilik özelliği yüksek olan kadınların zaman boyutu açısından aile-iş çatı̧̧masını daha az yaşadıkları belirtilmektedir (Batı ve İnel, 2015).

İzmir'de gerçekleştirilen bir çalışma; boşanmış kadın girişimcilerin iş yükünün, evli ve bekâr kadın girişimcilere göre daha fazla olduğunu, sağlık kalitesinin daha düşük olduğunu ve iş yaşam dengesini sağlayamadıklarını kaydetmiştir. İş yaşam dengesini en iyi sağlayan girişimciler, bekâr kadın girişimcilerdir (Ödemiş, 2018:121-122).

Çocukların sorumluluğuna sahip olmak kadın ve erkeklerde girişimcilik eğilimini çok farklı etkilemektedir. Erkeklerde girişimciliği önemli ölçüde yükseltmektedir; en küçük çocuğun okula başlama yaşına geldiği (6 yaş) durumda eğilim en yüksek düzeydedir. Kadınlar içinse en küçük çocuğun 3 yaşın altıda olduğu durumda olumsuz bir etki ortaya çıkmaktadır (Berglann vd., 2010: 17).

Bangladeş'te kadın girişimciler ve girişimci adayları başarıı bir kadın girişimcinin ideal ailesini şu şekilde tanımlamıştır: tek çocuk, okula giden tek çocuk, okula giden en küçük çocuğun yaşı sekiz olmalıdır; aile üyeleri büyük anne ve büyük baba dâhil beş kişiden oluşmalıdır (çocuğun büyütülmesine yardım ettikleri ve aileye katkıda bulundukları için) (Latif, Begum ve Lubna, 2015: 112). 
Brush vd. (2009) kadın girişimciler için cinsiyet temelli bir modelin gerekliliği üzerinde durmuş ve daha önce tüm girişimciler için oluşturulmuş olan 3M (money/para, management/yönetim market/pazar,) modeline iki yapı (motherhood/annelik, macro-meso environment/makromezo çevre) daha ekleyerek kadın girişimcilere özgü 5M modelini geliştirmişlerdir. Modeldeki yapılar kadınlar için bir girişimi başlatmak ve büyütmek sürecinde etkili unsurları ifade etmektedir.

DeMartino ve Barbato (2003: 815) kariyer motivasyonu ve cinsiyet arasındaki ilişkiyi araştırdıkları çalışmalarında benzer eğitim vb. şartlara sahip kadın ve erkek girişimciler arasındaki farklılıkların evli olma ve bakmakla yükümlü olduğu çocuk sahibi olma durumunda arttığ sonucuna ulaşmıştır.

Hindistan'da kadınların girişimciliği tercih etmemelerinin en büyük sebeplerinden biri evlendikten sonra nerede yerleşecekleri konusundaki belirsizliktir. Erkek egemen toplumda kadının kocasıyla gitmesi gerekmektedir, farklı bir yerden insanla evlenmesi durumunda girişimini kapatmaya zorlanması mümkün olabilmektedir (Baruah, 2010: 92).

Yine Hindistan'da gerçekleştirilen bir araştırmada, kadınların evlenmeden önce iş kurmaya daha az meyilli oldukları belirtilmektedir. Bunun sebebinin kadınların zihinlerine yerleşmiş derin bir endişe ve korunma güdüsü olduğu ifade edilmektedir. Evlilik, toplumsal baskılara karşı gelebilecek gücü onlara sağlayacaktır. Bu düşünce kadınlara, yanlış yönlendirici sosyal beklentiler ve ebeveynlerin korkusuyla yüklenmektedir. Kız çocuğunun evlendirilmesi en öncelikli ebeveyn görevidir. Ayrıca aileler kızlarının kendi işini kurması için destek sağlamaktansa evlendirilmesi için para harcamayı tercih etmektedir (Bose, 2012: 144).

\section{Türkiye'de Girişimcilik Araştırmalarında Medeni Durum Değişkeni}

Girişimcilik araştırmalarında medeni durum; yaş, cinsiyet ve eğitim gibi diğer demografik değişkenlerle birlikte örneklemin profili çizmek için kullanılmaktadır. Az sayıda çalışmada bu değişkenlerin bir veya birkaçını kullanarak analiz gerçekleştirilmiştir. Araştırmanın odak noktasına göre, eğitimin ve yaşın diğer değişkenlerle ilişkisi; medeni durum veya cinsiyete göre gruplar arasında farklılık bulunma durumu en çok kullanılan araştırma yöntemleridir.

Türkiye'de spesifik olarak evli ve bekâr kadın girişimciler arasındaki farklılıklar üzerine odaklanan çalışma bulunmamaktadır. Ancak girişimcilik ve kadın girişimciliği konusunda gerçekleştirilen saha araştırması içeren çalışmalarda medeni durum bir değişken olarak analize dâhil edilmiştir. Bu çalışmaların pek çoğu girişimci veya girişimci adaylarından oluşan örnekleme sahipken, kısıtlı sayıda çalışma kadın girişimciler üzerine uygulanmıştır.

Erdun (2011) tarafından Zonguldak’ta kadın girişimcilere uygulanan saha araştırması sonuçları içerisinde medeni durum değişkenine ilişkin analiz sonuçları bulunmaktadır. Analiz sonuçlarına göre kadın girişimcilerin medeni durumları ile risk alma eğilimleri ve kendilerine duydukları güven arasında anlamlı bir ilișki vardır. Evli kadın girişimcilerin risk alma eğilimleri ve kendilerine duydukları güven, bekâr kadın girişimcilere kıyasla daha yüksektir (Erdun, 2011: 80-83).
Ankara'da gerçekleştirilen bir saha araştırmasında kadın girişimcilerin medeni durumlarının çeşitli değişkenlerle ilişkisi, çapraz tablolar ile değerlendirilmiştir. Boşanmış girişimcilerin \%12,5'inin girişimciliği “işi bilmek” olarak, evlilerin ise \%10,13'ünün "cesaret" olarak tanımladıkları belirtilmiştir. Girişimcilik motivasyonu sorusuna bekârların \%33,33'ü "başkalarına faydalı olma isteği”, \%22,22'si ise "bağımsız olma isteği" olarak cevap vermiştir. Boşanmışların \%15,63'ü "başarma isteği” olarak tanımlamış, evlilerin ise $\% 0,45$ 'i "başarma isteği" ve $\% 15,91$ 'i "başkalarına faydalı olma isteğì" olarak belirtmiştir. Medeni durum ile karşılaşılan zorluklara bakıldığında, bekâr kadınların \%33,33'ü, boşanmışların \%23,53'ü ve evlilerin \%21,21'i kadın olmanın zorluğunu yaşadığını ifade etmiştir (Ankara Kalkınma Ajansı, 2014: 78-89).

Özyılmaz (2016) tarafından gerçekleştirilen çalışmanın Türkiye genelinde kadın girişimcilere uygulanan saha araştırması sonuçlarına göre, kadın girişimcilerin medeni durumu ile aile ihtiyaçlarını karşılamak için girişimci olma durumuna ilişkin uygulanan ki-kare bağımsızlık testi sonucunda istatistiksel açıdan anlamlı bir ilişki bulunmuştur. Hiç evlenmemiş olanların \%62,5'i aile ihtiyaçlarını karşılamak için girişimci olduğu önermesine katılırken, evli olanlarda bu oran $\% 84,5$ 'e, boşanmışlarda $\% 82,7$ ve eşi ölmüşlerde \%80'e çıkmaktadır (Özyılmaz, 2016: 111).

Ballı (2017: 52-58) tarafından Kozan'da gerçekleştirilen çalışmada kadın girişimci adaylarının uygulamalı girişimcilik eğitimine katılma nedenlerinin ve girişimci olmak isteme nedenlerinin evli olma durumuna göre farklılık göstermediği kaydedilmiştir. Çalışmada kadınlara sunulan ifadelerden 7 değişken kadınların eğitime katılma nedenlerini ve 14 değişken girişimci olmak isteme nedenlerini temsil etmektedir. Ayrıca çalışmada kadınların girişimcilik konusunda önlerinde gördükleri engeller açısından evli ve bekâr kadınlar arasında farklılık bulunmadığı ifade edilmektedir. Kadınlara engeller konusunda sunulan ifadeler: sermaye bulmanın zorluğu, aile izin ve desteğinin bulunmayışı, bürokratik işlemler, tecrübesizlik, işyeri açma maliyetleri, müşteri bulamama, donanım temininde güçlük, uygun eleman bulamama, başarısızlık korkusu, pazarda tanınmış olma ve toplumsal bask1.

Ödemiş (2018) tarafından İzmir'de gerçekleştirilen çalışmada, kadın girişimcilerin iş yaşam dengesinin; yaş, medeni durum, çalışma süresi, çalıştığı sektör, çocuk sahibi olma durumu, bakmakla yükümlü olduğu kişi varlığı ve ailesinde bakıma muhtaç kişi olma durumuna göre farklılık gösterdiği ve farkın anlamlı olduğu kaydedilmiştir. Analiz sonuçları, boşanmış kadın girişimcilerin iş yükünün, evli ve bekâr kadın girișimcilere göre daha fazla olduğunu, sağlık kalitesinin daha düşük olduğunu ve iş yaşam dengesini sağlayamadıklarını göstermiştir. İş yaşam dengesini en iyi sağlayan girişimciler, bekâr kadın girişimcilerdir. Boşanmış ve evli kadın girişimcilerin bekâr kadın girişimcilere göre iş yaşam dengesini sağlayamadıkları tespit edilmiştir (Ödemiş, 2018: 121-122).

Çetinoğlu ve Büber (2012) tarafından Ankara Ostim'de yürütülen bir saha araştırmasında girişimcilerin kişilik özellikleri ve kültürel değerlerinin, medeni durum, eğitim, yaş değiş̧kenleri açısından farklılık gösterme durumu araştırılmıştır. Örneklemin \%98,1'i erkek girişimcilerden 
oluşmaktadır. Araştırma sonucuna göre girişimci kişilik özellikleri (4 kişilik özelliği: pragmatik kişilik, moralist kişilik, duygusal kişilik, karışık kişilik) açısından evli ve bekâr girişimciler arasında anlamlı bir fark bulunmamıştır. Girişimciliğe yönlendiren özellikler (7 özellik: yenilikçilik, liderlik, otokontrol, risk alma, bağımsız olma, kendine güven, iyimserlik) açısından iki grup arasında iki ifadede istatistiksel olarak anlamlı farklılık bulunmuştur. $\mathrm{Bu}$ ifadelerin işaret ettiği özellikler "liderlik" ve "kendine güven" olarak tanımlanmış, evli girişimcilerin bekâr girişimcilere kıyasla daha yüksek ortalamalara sahip olduğu ifade edilmiştir. Kültürel değerler boyutu (Hofstede'nin beş kültür boyutu: erillik-dişillik, bireycilik-toplumculuk, güç mesafesi, belirsizlikten kaçınma ve uzun-kısa zamanlı oryantasyon) açısından iki grup arasında 7 ifadede anlamlı farklar bulunmuştur. $\mathrm{Bu}$ ifadelerin işaret ettiği özellikler "toplumculuk" ve "kısa zamanlı oryantasyon" olarak tanımlanmış, evli girişimcilerin bekâr girişimcilere kıyasla daha yüksek ortalamalara sahip olduğu ifade edilmiştir (Çetinoğlu ve Büber, 2012: 193-209).

Bayburt'ta mikro işletmelere uygulanan bir saha araştırmasında girişimci özelliklerinin sosyo-demografik özelliklere göre farklılık gösterme durumu araştırılmıştır. Örneklemin sadece \%4'ü kadınlardan oluşmaktadır. Analiz sonucunda medeni durum ile risk alma düzeyi arasında istatistiksel olarak anlamlı farklılık tespit edilmiştir. Evlilerin risk alma düzeyinin, bekârlardan daha yüksek olduğu görülmüştür (Kahya ve İmamoğlu, 2013: 1-9).

Girişimciliğin finansmanında melek sermayenin rolünü araştıran bir çalışmanın analiz sonuçlarına göre girişimciliğin finansmanında melek sermayenin rolünü değerlendirme düzeyleri, medeni durum açısından istatistiki olarak anlamlı bir farklılık göstermektedir. Bekâr girişimciler, evli olanlara kıyasla girişimcilik faaliyetlerinin finansmanında melek sermayenin kullanılması konusunda daha olumludurlar (Bingöl ve Türkmen, 2016: 367).

Orhan (2017) tarafindan gerçekleştirilen, girişimci eğilime kaderciliğin etkisinin araştırıldığı çalışmada girişimcilik potansiyeli belirleme ölçeği ve kadercilik eğilimi belirleme ölçeği kullanılmıştır. Örneklemin \%46,4'ü kadınlardan oluşmaktadır ve \%88,88'i girişimci değildir. Araştırma demografik faktörlerle analiz içermektedir. Analiz sonuçlarına göre, evli ya da bekâr olmanın girişimcilik potansiyelinde istatistiksel açıdan anlamlı bir fark oluşturmadığı kaydedilmiştir. Buna karşılık, evli katılımcıların genel kadercilik puanı ortalaması bekârların ortalamasına göre anlamlı şekilde yüksektir. Genel olarak, evli bireyler daha kaderci eğilimler göstermektedir. Evlilerin kontrol yoksunluğu puanı bekârların puanından istatistiksel açıdan anlamlı şekilde düşüktür. Ancak irrasyonel sebep sonuç ve alın yazısı/önceden belirlenmişlik boyutları açısından evlilerin puanı anlamlı şekilde yüksektir. Genel olarak, bekârlar olayları daha az kontrol edebildikleri hissi yaşarken, evliler daha fazla irrasyonel sebep-sonuç ilişkisi kurarak, alınyazısı/önceden belirlenmiş inancı yaşamaktadır. Araştırmada alt-boyutlar açısından da değerlendirme yapılmaktadır. Girişimcilik potansiyeli belirleme ölçeğinin inovatif yaratıcılı, ekonomik özgürlük motivasyonu, risk eğilimi, sosyal ağlar geliştirme alt-boyutlarında bekârların puanlarının istatistiki anlam içerecek şekilde daha yüksek bulunduğu ifade edilmektedir. Boyutlara bakıldığında, girişimci motivasyonlar, sosyal yetkinlikler boyutları açısından bekârların puanları daha yüksektir. Genel puanda medeni durum açısından farklılık bulunmasa da bekârlar daha yaratıcı inovasyon gösterme, ekonomik özgürlüğünü sağlama motivasyonunu sağlama çabası gösterme potansiyeline sahiptir. Daha fazla risk alma ve sosyal ağlar kurma potansiyeli sergilemiştir. Evli bireyler, toplumsal normlardan daha fazla etkilenerek, daha ortalama normları benimsemektedir. Ayrıca evli veya bekâr olmanın yaşla da etkileşime girdiği düşünülmektedir (Orhan, 2017: 147-150).

Mesleki eğitim gören üniversite öğrencilerinin kültürel zeka düzeyleri ile bireysel girişimcilik yönelimleri arasındaki ilişkiyi tespit etme amacıyla İç Anadolu Bölgesinde faaliyet gösteren bir üniversitenin meslek yüksekokulunda saha araştırması gerçekleştirilmiştir. Örneklemin \%46,8'i kadınlardan oluşmaktadır. Öğrencilerin medeni durumları ile üst biliş boyutu arasında anlamlı bir ilişki bulunmuştur. Evli öğrencilerin bekârlara göre üst biliş puanlarının yüksek olduğu tespit edilmiştir. Öğrencilerin demografik özellikleri ile bireysel girişimcilik yönelimleri alt boyutları arasındaki anlamlı ilişkiye yönelik yapılan analizlerde, medeni durum ile yenilikçilik arasında anlamlı ilişkiler tespit edilmiştir. Evli öğrencilerin yenilikçilik puanlarının bekârlara göre yüksek olduğu tespit edilmiştir (Gürer ve Çiftçi, 2018: 496500).

Son yıllarda Türkiye'de çok yaygın bir şekilde uygulamalı girişimcilik eğitimleri verilmektedir. KOSGEB yeni girişimci desteklerinden faydalanmanın bir ön koşulu olarak uygulamalı girişimcilik eğitimlerine katılımın tanımlanmış olması, ülke çapında girişimcilik eğitimlerinin yaygınlaşmasına sebep olmuştur (Türko, 2016a: 61). Girişimci adayı veya potansiyel girişimci olarak nitelendirilen katılımcı gruplarına eğitim öncesi ve/veya sonrası uygulanan anketler ile gerçekleştirilen çok sayıda çalışma bulunmaktadır. Bu çalışmalarda örneklem genel olarak kadın ve erkeklerden oluşmaktadır. Giresun'da gerçekleştirilen bir çalışmada evli olma durumu ile girişimcilik eğilimleri arasında anlamlı bir ilişki bulunmamıştır (Genç, 2015: 171). Benzer bir sonuç Edirne, Kırklareli, Tekirdağ bölgesinde gerçekleştirilen bir araştırmada kaydedilmiş, girişimcilik eğitimi alan katılımcıların medeni durumlarının girişimcilik eğilimleri üzerinde istatistiksel olarak anlamlı bir etkisinin olmadığ kaydedilmiştir (Altuntaş, 2016: 35, 40). KOSGEB Girişimcilik eğitimlerine katılanların girişimcilik kararını etkileyen sebepleri araştıran bir diğer çalışma sonuçlarına göre bekâr ve evli katılımcıların ankete verdikleri cevaplar 3 ifadede istatistiksel olarak farklılık göstermektedir. Bekâr katılımcıların başkaları tarafından saygı görmeye değer verdikleri; evli katılımcıların ise kendilerine, eşlerine ve çocuklarına güven vermeye; aynı düşünce ve görüşleri paylaştıkları insanların gelişimine katkıda bulunmaya daha fazla önem verdikleri kaydedilmiştir. İnce vd. bu farklılı̆̆ın sebebinin; bekârların diğerlerine karşı sorumluluk hissetmemeleri, buna karşın evlilerin ailevi sorumluluklarını yerine getirmek zorunda olmaları ve sosyal ilişkilere önem vermeleri ile açıklanabileceğini ifade etmektedir (İnce vd., 2016: 120).

\section{Yöntem}

Erzurum Esnaf ve Sanatkarlar Odası Başkanlığına (ESOB) kayıtlı Erzurum il merkezinde (Yakutiye, Aziziye ve Palandöken ilçelerinde) faaliyet gösteren kadın girişimci 
sayıs1 722'dir. Erzurum Ticaret ve Sanayi Odası'na kayıtlı (ETSO) kadın girişimci sayısı 69'dur. Araştırmanın ana kütlesi, ESOB ve ETSO’ya kayıtlı 791 kadın girişimciden oluşmaktadır. Örneklem, \%95 güven seviyesinde ve 0,05 güven aralığında www.surveysystem.com websitesi üzerinden (sample size calculator uygulaması kullanılarak) 259 olarak hesaplanmıştır (Survey System, 2017).

Anket formu, kadın girişimciliği konusunda geniş bir literatür taraması yapıldıktan sonra, daha önce yapılan saha çalışmaları incelenerek araştırmacılar tarafindan oluşturulmuştur. Anket formundaki iyi anlaşılamayan veya tartışmalı ifadeleri belirlemek amacıyla araştırmacılar tarafindan Erzurum ilinde faaliyet gösteren 20 kadın girişimciye ön anket yapılmıştır. Bu şekilde, anket formuna son şekli verilmeden önce anket formu test edilmiş, soruların anlaşılırlığı, soruluş sırası ve cevaplama süresi saptanmıştır. 20 işletme ile derinlemesine görüşmeler gerçekleştirilmiştir.

Ön anket uygulamasından yola çıkılarak anket formunda gerekli düzenlemeler gerçekleştirilmiş ve forma son şekli verilmiştir. Ayrıca araştırmada kullanılacak analiz yöntemlerine uygun olarak bazı sorular yeniden düzenlenmiştir. Veri toplamak için geliştirilen anket 2017 yılının Nisan-Haziran ayları arasında Erzurum ilinin çeşitli semtlerinde farklı sektördeki kadın girişimcilere yüz yüze görüşme tekniğiyle uygulanmıştır. Saha araştırması kapsamında 228 işletme ziyaret edilmiştir. 200 işletme anket uygulamayı kabul etmiş, 19 işletme ise reddetmiştir. Ayrıca 9 işletmenin kadın girişimci adına açılmasına rağmen erkekler tarafindan işletildiği tespit edilmiş, bu işletmelere anket uygulanmamıştır. Saha araştırması kapsamında 200 anket uygulanmıştır.

Çeşitli sebeplerle hedeflenen örneklemin tamamına ulaşılamadığı için araştırma sonuçları 200 kadın girişimciden elde edilen veriler ile sınırlıdır. Ayrıca sosyal bilimlerdeki araştırmalara özgü genel sınırlılıklar, bu araştırma için de geçerlidir.

Anket formu iki ana bölüm ve 35 sorudan oluşmaktadır. Sorular 5'li Likert ölçeği ile seçeneklendirilmiştir (1kesinlikle hayır, 2-hayır, 3-kararsızım, 4-evet, 5-kesinlikle evet). İlk bölüm genel bilgiler ve çalışma koşullarına yönelik sorular içermektedir. İkinci bölüm işletmeyi kurarken, yönetirken ve işletmeyi kurduktan sonra kadın girişimcilerin karşılaştıkları problemleri belirlemeye yönelik sorular içermektedir. Anket formunun güvenirliği Cronbach Alpha katsayısı hesaplanarak belirlenmiştir. Alpha değeri 0,805'tir ve anketin güvenilir olduğunu göstermektedir. Analizler SPSS 22 paket programı ile gerçekleştirilmiştir.

\section{Analiz}

Evli ve bekâr kadın girişimciler arasında çeşitli değişkenler açısından anlamlı bir farklılık bulunup bulunmadığı araştırmak amacıyla kullanılan fark testinin seçimi için veri seti önce kategorize edilmiş değişkenler Tek Örneklem Kolmogorov Smirnov testi ile değerlendirilmiştir. Değişkenlerin normal bir dağılım göstermediği tespit edildikten sonra $(\mathrm{p}=0,00<0,05)$ parametrik olmayan Mann Whitney U testinin kullanılmasına karar verilmiştir.

Mann-Whitney U testi, aralıksız ölçülen (kategorik) 2 bağımsız grup arasında (evli-bekâr, kadın-erkek vb.) farkl11.k bulunma durumunu araştırmak için kullanılmaktadır. Bağımsız örneklem t-testinin parametrik olmayan alternatifidir. İki grubun karşılaştırması yapılırken t-testinde iki grubun ortalama değerleri, Mann-Whitney U testinde ise ortanca değerleri karşılaştırılır. Mann-Whitney U istatistiği, sürekli değişkenlerin, iki grup içinde, değerlerini sıralı hale dönüştürür. Böylece iki grup arasındaki sıralamanın farklı olup olmadığını değerlendirir. Değerler sıralı hale dönüştürüldüğü için, değerlerin asıl dağılımları önemli değildir (Kalaycı, 2017 : 99; Durmuş vd., 2013: 188). Araştırmada gruplandırma için kullanılan kategorik değişken medeni durumdur, örneklemde evli ve bekâr kadın girişimciler arasında farklılık bulunma durumu araştırılmıştır. İki grup arasında değişiklik bulunma durumu araştırılan değişkenler sıralı ve aralıklı ölçek ile ölçülmüştür.

Tablo gösteriminde kolaylık olması için bekâr kadın girişimciler "0", evli kadın girişimciler "1" kodları kullanılarak kategorize edilmiştir. Evli ve bekâr kadın girişimciler arasında istatistiksel olarak anlamlı bir fark bulunması durumunda $(\mathrm{p}<0,05)$ değişkenin sıra ortalaması ve p değeri kalın olarak gösterilmiştir. Örneklem içinde 62 bekâr, 138 evli kadın girişimci bulunmaktadır. Dul, boşanmış veya medeni durumunu belirtmek istemeyen kadın girişimciler bekâr olarak kaydedilmiştir.

Tablo 1. Evli ve Bekâr Kadın Girişimciler Arasında Eğitim Düzeyi ve Yaş Açısından Farklılık Bulunma Durumu

\begin{tabular}{|c|c|c|c|c|c|c|c|c|}
\hline & & $\mathrm{N}$ & Sira ortalamas1 & Siraların toplamı & Mann Whitney U & Wilcoxon W & $\mathrm{Z}$ & $p$ değeri \\
\hline Eğitim Düzeyi & $\begin{array}{l}0 \\
1\end{array}$ & $\begin{array}{c}62 \\
138\end{array}$ & $\begin{array}{c}118,28 \\
92,51\end{array}$ & $\begin{array}{c}7333,50 \\
12766,50\end{array}$ & 3175,500 & 12766,50 & -3.336 & ,001 \\
\hline Yaş & $\begin{array}{l}0 \\
1\end{array}$ & $\begin{array}{c}62 \\
138\end{array}$ & $\begin{array}{c}66,53 \\
115,76\end{array}$ & $\begin{array}{c}4125,00 \\
15975,00\end{array}$ & 2172,000 & 4125,000 & -5.801 & ,000 \\
\hline
\end{tabular}

Tablo 2. Evli ve Bekâr Kadın Girişimciler Arasında İşletme Sahibi Oldukları Yıı Sayısı ve Çalışan Sayısı Açısından Farklılık Bulunma Durumu

\begin{tabular}{|c|c|c|c|c|c|c|c|c|}
\hline & & $\mathrm{N}$ & Sira ortalamas1 & Siraların toplamı & Mann Whitney U & Wilcoxon W & $\mathrm{Z}$ & $p$ değeri \\
\hline Kaç yıldır işletme sahibisiniz? & $\begin{array}{l}0 \\
1\end{array}$ & $\begin{array}{c}62 \\
138\end{array}$ & $\begin{array}{l}100,79 \\
100,37\end{array}$ & $\begin{array}{c}6249,00 \\
13851,00\end{array}$ & 4260,000 & 13851,000 &,- 049 & ,961 \\
\hline Çalışan Sayısı & $\begin{array}{l}0 \\
1 \\
\end{array}$ & $\begin{array}{c}62 \\
138 \\
\end{array}$ & $\begin{array}{c}94,50 \\
103,20 \\
\end{array}$ & $\begin{array}{c}5859,00 \\
14241,00 \\
\end{array}$ & 3906,000 & 5859,00 & -2.389 &, 017 \\
\hline
\end{tabular}


Tablo 3. Evli ve Bekâr Kadın Girişimciler Arasında Çalışma Koşulları ve İşi Bırakma İstekleri Açısından Farklılık Bulunma Durumu

\begin{tabular}{|c|c|c|c|c|c|c|c|c|}
\hline & & $\mathrm{N}$ & Sira ort. & Siraların top. & Mann Whitney U & Wilcoxon W & $\mathrm{Z}$ & $p$ değeri \\
\hline Günde kaç saat çalışıyorsunuz? & $\begin{array}{l}0 \\
1\end{array}$ & $\begin{array}{c}61 \\
137\end{array}$ & $\begin{array}{c}102,10 \\
98,34\end{array}$ & $\begin{array}{c}6228,00 \\
13473,00\end{array}$ & 4020,000 & 13473,000 &,- 461 & ,645 \\
\hline $\begin{array}{l}\text { Eve iş götürür müsünüz/veya evde üretim yapıp } \\
\text { işletmede satar mısınız? }\end{array}$ & $\begin{array}{l}0 \\
1\end{array}$ & $\begin{array}{c}62 \\
138 \\
\end{array}$ & $\begin{array}{c}104,06 \\
98,90\end{array}$ & $\begin{array}{c}6452,00 \\
13648,00\end{array}$ & 4057,000 & 13648,000 &,- 787 & ,432 \\
\hline $\begin{array}{l}\text { Ailenize dilediğiniz gibi vakit ayırabiliyor } \\
\text { musunuz? }\end{array}$ & $\begin{array}{l}0 \\
1\end{array}$ & $\begin{array}{c}62 \\
138 \\
\end{array}$ & $\begin{array}{l}100,39 \\
100,55\end{array}$ & $\begin{array}{c}6224,00 \\
13876,00\end{array}$ & 4271,000 & 6224,000 &,- 019 & ,985 \\
\hline $\begin{array}{l}\text { Bugün imkanınız olsa bırakır mıydınız? veya } \\
\text { maaşlı bir işe geçer miydiniz? }\end{array}$ & $\begin{array}{l}0 \\
1\end{array}$ & $\begin{array}{c}62 \\
138 \\
\end{array}$ & $\begin{array}{c}98,95 \\
101,20 \\
\end{array}$ & $\begin{array}{c}6135,00 \\
13965,00 \\
\end{array}$ & 4182,000 & 6135,000 &,- 282 & ,778 \\
\hline Ailenizin toplam aylık geliri ne kadardır? & $\begin{array}{l}0 \\
1\end{array}$ & $\begin{array}{c}62 \\
138\end{array}$ & $\begin{array}{c}91,75 \\
103,65\end{array}$ & $\begin{array}{c}5596,50 \\
14303,50\end{array}$ & 3705,500 & 5596,500 & $-1,414$ &, 157 \\
\hline
\end{tabular}

Eğitim düzeyi ve yaş açısından evli ve bekâr kadın girişimciler arasında istatistiksel olarak anlamlı farklılıklar mevcuttur (Tablo 1). Evli girişimcilere kıyasla, bekâr kadın girişimcilerin eğitim düzeyi daha yüksektir, yaş ortalaması ise daha düşüktür.

Çalışan sayısı açısından evli ve bekâr kadın girişimciler arasında istatistiksel olarak anlamlı bir farklılık bulunmuştur. Bekâr girişimcilere kıyasla evli kadın girişimciler daha fazla sayıda çalışan istihdam etmektedir. Diğer yandan evli ve bekâr kadın girişimciler arasında işletme sahibi oldukları yıl sayısı açısından anlamlı bir farklılik yoktur (Tablo 2).

Kadın girişimcilere çalıșma koşulları konusunda yöneltilen sorular Tablo 3 'te sunulmuştur. Günlük çalışma saati, eve iş götürme, aileye dilediği gibi vakit ayırabilme, imkânı olsa işi bırakma isteği, ailenin toplam geliri değişkenleri açısından iki grup arasında istatistiksel olarak anlamlı bir farklılık yoktur.

Girişimcilere işletmeyi kurarken karşılaştıkları sorunlara ilişkin çeşitli ifadeler sunulmuş ve bu ifadeler Tablo 4'te listelenmiştir. Evli ve bekâr kadın girişimciler arasında işletmeyi kurarken karşılaşılan sorunlar açısından istatistiksel olarak anlamlı bir farklılık yoktur. Başka bir ifadeyle, evli ve bekâr kadın girişimciler işletmeyi kurarken benzer düzeylerde aile ve yakın çevrelerinden olumsuz baskı hissetmiş, bürokratik işlemlerde, işi planlamada, makine ve ekipman seçim ve temininde, finansal kaynak bulmada sorun yaşamıştır.

Tablo 4. Evli ve Bekâr Kadın Girişimciler Arasında İşletmeyi Kurarken Karşıllaştıkları Sorunlar Açısından Farklılık Bulunma Durumu

\begin{tabular}{|c|c|c|c|c|c|c|c|c|}
\hline & & $\mathrm{N}$ & Sira ortalamas1 & Siraların toplamı & Mann Whitney U & Wilcoxon W & $\mathrm{Z}$ & $p$ değeri \\
\hline $\begin{array}{l}\text { Ailem ve yakın çevremin olumsuz } \\
\text { baskısını hissettim. }\end{array}$ & $\begin{array}{l}0 \\
1 \\
\end{array}$ & $\begin{array}{c}62 \\
138 \\
\end{array}$ & $\begin{array}{c}95,66 \\
102,67\end{array}$ & $\begin{array}{c}5931,00 \\
14169,00 \\
\end{array}$ & 3978,000 & 5931,000 &,- 863 & ,388 \\
\hline Bürokratik işlemlerde zorlandım. & $\begin{array}{l}0 \\
1 \\
\end{array}$ & $\begin{array}{c}62 \\
138 \\
\end{array}$ & $\begin{array}{l}100,31 \\
100,58\end{array}$ & $\begin{array}{c}6219,50 \\
13880,50 \\
\end{array}$ & 4266,500 & 6219,500 &,- 034 & ,973 \\
\hline İşi planlamakta zorlandım. & $\begin{array}{l}0 \\
1\end{array}$ & $\begin{array}{c}62 \\
138 \\
\end{array}$ & $\begin{array}{c}104,35 \\
98,77\end{array}$ & $\begin{array}{c}6469,50 \\
13630,50\end{array}$ & 4039,500 & 13630,500 & -,784 & ,433 \\
\hline $\begin{array}{l}\text { Makine ekipman seçiminde ve } \\
\text { temininde zorlandım. }\end{array}$ & $\begin{array}{l}0 \\
1 \\
\end{array}$ & $\begin{array}{c}62 \\
138 \\
\end{array}$ & $\begin{array}{c}108,44 \\
96,18 \\
\end{array}$ & $\begin{array}{c}6723,50 \\
13176,50 \\
\end{array}$ & 3723,500 & 13176,500 & $-1,658$ & ,097 \\
\hline Finansal kaynak bulmakta zorlandım. & $\begin{array}{l}0 \\
1 \\
\end{array}$ & $\begin{array}{c}62 \\
138 \\
\end{array}$ & $\begin{array}{c}104,40 \\
98,75\end{array}$ & $\begin{array}{c}6473,00 \\
13627,00 \\
\end{array}$ & 4036,000 & 13627,000 & -.697 & ,486 \\
\hline
\end{tabular}

Tablo 5. Evli ve Bekâr Kadın Girişimciler Arasında İşletmeyi Yönetirken Karşılaştıkları Sorunlar Açısından Farklılık Bulunma Durumu

\begin{tabular}{|c|c|c|c|c|c|c|c|c|}
\hline & & $\mathrm{N}$ & Sira ortalamas1 & Siraların toplamı & Mann Whitney U & Wilcoxon W & $\mathrm{Z}$ & $p$ değeri \\
\hline \multirow{2}{*}{ Pazarlama konusunda zorlandım. } & 0 & 62 & 108,23 & 6710,00 & \multirow{2}{*}{3799,000} & \multirow{2}{*}{13390,00} & \multirow{2}{*}{$-1,494$} & \multirow{2}{*}{135} \\
\hline & 1 & 138 & 97,03 & 13390,00 & & & & \\
\hline \multirow{2}{*}{ Finansal hesaplar konusunda zorlandım. } & 0 & 62 & 101,16 & 6272,00 & \multirow{2}{*}{4237,000} & \multirow{2}{*}{13828,00} & \multirow{2}{*}{,- 124} & \multirow{2}{*}{,901 } \\
\hline & 1 & 138 & 100,20 & 13828,00 & & & & \\
\hline \multirow{2}{*}{ Müşteri ilişkilerinde zorlandım. } & 0 & 62 & 107,52 & 6666,50 & \multirow{2}{*}{3842,500} & \multirow{2}{*}{13433,500} & \multirow{2}{*}{$-1,448$} & \multirow{2}{*}{, 148} \\
\hline & 1 & 138 & 97,34 & 13433,50 & & & & \\
\hline \multirow{2}{*}{ Üretim miktarını belirlerken zorlandım. } & 0 & 62 & 103,62 & 6321,00 & \multirow{2}{*}{3866,000} & \multirow{2}{*}{13182,000} & \multirow{2}{*}{,- 973} & \multirow{2}{*}{ 331 } \\
\hline & 1 & 138 & 96,93 & 13182,00 & & & & \\
\hline \multirow{2}{*}{ Üretim sorunlarını çözmekte zorlandım. } & 0 & 62 & 104,89 & 6398,00 & \multirow{2}{*}{3728,000} & \multirow{2}{*}{12908,000} & \multirow{2}{*}{$-1,332$} & \multirow{2}{*}{, 183} \\
\hline & 1 & 138 & 95,61 & 12908,00 & & & & \\
\hline \multirow{2}{*}{ Satış fiyatlarını belirlerken zorlandım. } & 0 & 61 & 113,39 & 6917,00 & \multirow{2}{*}{3331,000} & \multirow{2}{*}{12784,000} & \multirow{2}{*}{$-2,748$} & \multirow{2}{*}{,006 } \\
\hline & 1 & 137 & 93,31 & 12784,00 & & & & \\
\hline \multirow{2}{*}{ Çalışanları yönetmekte zorlandım. } & 0 & 62 & 107,20 & 6646,50 & \multirow{2}{*}{3738,500} & \multirow{2}{*}{13054,500} & \multirow{2}{*}{$-1,505$} & \multirow{2}{*}{,132 } \\
\hline & 1 & 138 & 95,99 & 13054,50 & & & & \\
\hline \multirow{2}{*}{ Rakiplerimle başa çıkmakta zorlandım. } & 0 & $\begin{array}{c}61 \\
137\end{array}$ & 101,75 & 6206,50 & 4041,500 & 13494,500 &,- 446 & ,656 \\
\hline & 1 & 137 & 98,50 & 13494,50 & & & & \\
\hline
\end{tabular}


Tablo 6. Evli ve Bekâr Kadın Girişimciler Arasında İşletmeyi Kurduktan Sonra Karşılaştıkları Sorunlar Açısından Farklılık Bulunma Durumu

\begin{tabular}{|c|c|c|c|c|c|c|c|c|}
\hline & & $\mathrm{N}$ & Sira ort. & Siraların top. & Mann Whitney U & Wilcoxon W & $\mathrm{Z}$ & $p$ değeri \\
\hline $\begin{array}{l}\text { Kadın olduğum için önyargılı tutum ve } \\
\text { ayrımcılığa maruz kaldım. }\end{array}$ & $\begin{array}{l}0 \\
1\end{array}$ & $\begin{array}{c}62 \\
138\end{array}$ & $\begin{array}{l}100,60 \\
100,46\end{array}$ & $\begin{array}{c}6237,00 \\
13863,00\end{array}$ & 4272,000 & 13863,000 &,- 017 & ,986 \\
\hline Ev kadını sorumluluklarımı aksatmaya başladım. & $\begin{array}{l}0 \\
1 \\
\end{array}$ & $\begin{array}{c}62 \\
138 \\
\end{array}$ & $\begin{array}{c}28 \\
136 \\
\end{array}$ & $\begin{array}{l}77,66 \\
83,50 \\
\end{array}$ & 1768,500 & 2174,500 &,- 640 &, 522 \\
\hline İş kurarken yakın çevreden destek olanların sayısı & $\begin{array}{l}0 \\
1\end{array}$ & $\begin{array}{c}61 \\
138 \\
\end{array}$ & $\begin{array}{c}91,79 \\
103,63\end{array}$ & $\begin{array}{c}5599,00 \\
14301,00\end{array}$ & 3708,000 & 5599,000 & $-1,535$ &, 125 \\
\hline Aile içi sorumluluklar işlerimi aksatmaya başladı. & $\begin{array}{l}0 \\
1\end{array}$ & $\begin{array}{c}62 \\
137\end{array}$ & $\begin{array}{c}102,78 \\
98,74\end{array}$ & $\begin{array}{c}6372,50 \\
13527,50\end{array}$ & 4074,500 & 13527,500 &,- 527 & ,598 \\
\hline
\end{tabular}

Tablo 7. Evli ve Bekâr Kadın Girişimciler Arasında Çevresel Destekleyici Koşullar Konusundaki Görüşleri Açısından Farklılık Bulunma Durumu

\begin{tabular}{|c|c|c|c|c|c|c|c|}
\hline & $\mathrm{N}$ & Sira ort. & Siraların top. & Mann Whitney U & Wilcoxon W & $\mathrm{Z}$ & $p$ değeri \\
\hline $\begin{array}{l}\text { Çalıştığım sektörde büyümek için uygun firsatlar } \\
\text { görüyorum. }\end{array}$ & $\begin{array}{lc}0 & 62 \\
1 & 137 \\
\end{array}$ & $\begin{array}{l}103,00 \\
98,64\end{array}$ & $\begin{array}{c}6386,00 \\
13514,00\end{array}$ & 4061,000 & 13514,000 &,- 538 & ,590 \\
\hline $\begin{array}{l}\text { Çalıştığım sektörün kadın girişimciler için çok uygun } \\
\text { olduğunu düşünüyorum. }\end{array}$ & $\begin{array}{lc}0 & 62 \\
1 & 138 \\
\end{array}$ & $\begin{array}{c}99,52 \\
100,94 \\
\end{array}$ & $\begin{array}{r}6170 \\
1393( \\
\end{array}$ & 000 & 6170,00 &,- 196 & ,845 \\
\hline $\begin{array}{l}\text { Yaşadığım bölgede hakim olan kültür kadınları } \\
\text { girişimci olmaya teşvik ettiğini düşünüyorum. }\end{array}$ & $\begin{array}{lc}0 & 61 \\
1 & 138 \\
\end{array}$ & $\begin{array}{c}92,97 \\
103,11 \\
\end{array}$ & $\begin{array}{c}5671,00 \\
14229,00 \\
\end{array}$ & 3780,000 & 5671,000 & $-1,213$ & ,225 \\
\hline $\begin{array}{l}\text { Yaşadığım bölgede kadın girişimciler için yeterli destek } \\
\text { mekanizmalarının bulunduğunu düşünüyorum. }\end{array}$ & \begin{tabular}{cc|}
0 & 62 \\
1 & 138 \\
\end{tabular} & $\begin{array}{c}95,91 \\
102,56\end{array}$ & $\begin{array}{c}5946,50 \\
14153,50\end{array}$ & 00 & 00 &,- 818 & ,413 \\
\hline $\begin{array}{l}\text { Kadın olduğum için erkek girişimcilerin karşılaşmadığ } 1 \\
\text { türden sorunlarla karşılaştığımı düşünüyorum. }\end{array}$ & $\begin{array}{ll}0 & 61 \\
1 & 138 \\
\end{array}$ & $\begin{array}{c}99,80 \\
100,09 \\
\end{array}$ & $\begin{array}{c}6088,00 \\
13812,00 \\
\end{array}$ & 4197,000 & 6088,00 &,- 034 & ,973 \\
\hline
\end{tabular}

Tablo 8. Evli ve Bekâr Kadın Girişimciler Arasında İşletmeyi Yönetmekte Zorlanma Durumları Açısından Farklılık Bulunma Durumu

\begin{tabular}{lcccccccc}
\hline & & $\mathrm{N}$ & Sıra ortalamas1 & Sıraların toplamı & Mann Whitney U & Wilcoxon W & Z & $p$ değeri \\
\hline \multirow{2}{*}{ I̧sletmeyi yönetmekte zorlanmıorum } & 0 & 62 & 108,02 & 6697,00 & \multirow{2}{*}{3812,000} & \multirow{2}{*}{13403,000} & $-1,309$ & \multirow{2}{*}{, 190} \\
& 1 & 138 & 97,12 & 13403,00 & & & & \\
\hline
\end{tabular}

Girişimcilere işletmeyi yönetirken karşılaştıkları sorunlara ilişkin çeşitli ifadeler sunulmuş ve bu ifadeler Tablo 5'te listelenmiştir. Evli ve bekâr kadın girişimciler arasında işletmeyi kurarken karşılaşılan sorunlar konusunda sunulan 8 değişkenin 7'sinde istatistiksel olarak anlamlı bir farklılık yoktur. Başka bir ifadeyle, evli ve bekâr kadın girişimciler işletmeyi yönetirken pazarlama, finansal hesaplar, müşteri ilişkileri, üretim miktarını belirleme, üretim sorunlarını çözme, çalışanları yönetme ve rakiplerle başa çıkma konularında benzer düzeylerde sorun yaşamıştır. Diğer yandan satış fiyatlarını belirleme konusunda iki grup arasında anlamlı bir farklılık bulunmaktadır. Bekâr kadın girişimciler, evlilere kıyasla satış fiyatlarını belirleme konusunda daha çok zorlanmıştır.

Girişimcilere işletmeyi kurduktan sonra karşılaştıkları sorunlara ilişkin çeşitli ifadeler sunulmuş ve bu ifadeler Tablo 6'da listelenmiştir. Evli ve bekâr kadın girişimciler arasında işletmeyi kurduktan sonra karşılaşılan sorunlar açısından istatistiksel olarak anlamlı bir farklılık yoktur. İşletmeyi kurduktan sonra önyargılı tutum ve ayrımcılığa maruz kalma, ev kadını sorumluluklarını aksatmaya başlama, aile içi sorumlulukların işi aksatması, yakın çevreden destek olanların sayısı açısından iki grup arasında farklılık bulunmamıştır.

Kadın girişimcilere faaliyette bulundukları bölgede geçerli olan çevresel destekleyici koşullara ilişkin çeşitli ifadeler sunulmuş ve bu ifadeler Tablo 7'de listelenmiştir. Evli ve bekâr kadın girişimciler arasında çevresel destekleyici koşullar açısından istatistiksel olarak anlamlı bir farklılık bulunmamaktadır. Kadın girişimciler benzer düzeylerde çalıştıkları sektörde büyümek için uygun firsatlar görmekte ve sektörün kadın girişimciler için uygun olduğunu düşünmektedir. Ayrıca evli ve bekâr kadınlar yaşadıkları bölgede hakim olan kültürün kadınları girişimci olmaya teşvik ettiğini ve kadın girişimciler için yeterli destek mekanizmalarının bulunduğunu, benzer düzeylerde ifade etmiştir. Kadın olduğu için erkek girişimcilerin karşılaşmadığı türden sorunlarla karşılaştığını düşünme durumu açısından iki grup arasında farklılık bulunmamıştır.

Evli ve bekâr kadın girişimciler arasında işletmeyi yönetmekte zorlanma düzeyi açısından istatistiksel olarak anlamlı bir farklılık yoktur (Tablo 8). Kadın girişimciler işletmeyi yönetirken zorlanma durumlarını benzer düzeylerde ifade etmiştir.

\section{Sonuç ve Öneriler}

Evli ve bekâr kadın girişimciler arasında çeşitli değişkenler açısından farklılık bulunma durumunun araştırıldığı bu çalışmada Erzurum il merkezinde çeşitli sektörlerde faaliyet gösteren 200 kadın girişimciye saha araştırması uygulanmıştır. Araştırmanın ataerkil toplumsal yapı nedeniyle güçlü kalıpyargıların bulunduğu düşünülen bir bölgede Erzurum'da gerçekleştirilmesi tercih edilmiştir. Uygulama sonuçlarının bölgede kadın girişimciliğinin desteklenmesi konusunda tasarlanacak programlara katkıda bulunması beklenmektedir.

Analiz sonuçları kadın girişimciler arasında 32 değişkenin sadece 4 tanesinde evli olma durumuna göre farklılık bulunduğunu göstermektedir. Evli girişimciler, bekâr girişimcilere kıyasla daha düşük eğitim seviyesine ve daha yüksek yaş ortalamasına sahiptir, daha çok çalışan istihdam etmektedir ve satış fiyatlarını belirlemede daha az zorlandığını ifade etmiştir.

Diğer yandan evli ve bekâr kadın girişimciler arasında 28 değişkende istatistiksel olarak anlamlı bir farklılık bulunmadığı tespit edilmiştir. Günlük çalışma saati, eve iş götürme, aileye dilediği gibi vakit ayırabilme, imkânı olsa işi 
bırakma isteği, ailenin toplam geliri değişkenleri açısından iki grup arasında farklılık yoktur.

Evli ve bekâr kadın girişimciler işletmeyi kurarken benzer düzeylerde aile ve yakın çevrelerinden olumsuz baskı hissetmiş, bürokratik işlemlerde, işi planlamada, makine ve ekipman seçim ve temininde, finansal kaynak bulmada sorun yaşamıştır. Ayrıca işletmeyi yönetirken zorlanma düzeyleri de benzerdir. Araştırma sonuçları Ballı (2017) tarafından Kozan'da kadın girişimci adaylarına uygulanan saha araştırması sonuçlarını desteklemektedir. Söz konusu araştırmada kadınların girişimcilik konusunda önlerinde gördükleri engeller açısından evli ve bekâr kadınlar arasında farklılık bulunmadığ 1 ifade edilmektedir. Kadınlara engeller konusunda sunulan ifadeler: sermaye bulmanın zorluğu, aile izin ve desteğinin bulunmayışı, bürokratik işlemler, tecrübesizlik, işyeri açma maliyetleri, müşteri bulamama, donanım temininde güçlük, uygun eleman bulamama, başarısızlık korkusu, pazarda tanınmış olma ve toplumsal baskıdır.

Kadın girişimcinin evli olması durumunda ev işlerini ve çocukların bakımını aksatacağı veya ev işlerinin işletme yönetimini aksatacağı ve kadını başarısızlığa sürükleyeceği yönünde bir kalıpyargı bulunmaktadır (Türko, 2016b). İşletmeyi kurduktan sonra önyargılı tutum ve ayrımcılığa maruz kalma, ev kadını sorumluluklarını aksatmaya başlama, aile içi sorumlulukların işi aksatması, yakın çevreden destek olanların sayısı açısından iki grup arasında farklılık yoktur. Araştırma, toplumsal cinsiyet rollerinden beslenen bu kalıpyargı hakkında uygulamalı çalışmalarla aynı yönde bir sonuç ortaya koymakta, kadınların çatışma odaklarını stratejiler geliştirerek çözdüklerini göstermektedir (Batı ve İnel, 2015). Diğer yandan araştırma sonuçları Ödemiş (2018) tarafından İzmir'de gerçekleştirilen araştırma sonuçlarını desteklememektedir. İş yaşam dengesini en iyi sağlayan girişimcilerin, bekâr kadın girişimciler olduğu kaydedilen söz konusu araştırmada medeni durum değişkeni, bu çalışmadan farklı olarak evli, bekâr, boşanmış olarak daha detaylı bir şekilde kategorize edilmiştir.

Kadın girişimciler benzer düzeylerde çalıştıkları sektörde büyümek için uygun firsatlar görmekte ve sektörün kadın girişimciler için uygun olduğunu düşünmektedir. Evli ve bekâr girişimciler arasında, yaşadıkları çevreyi değerlendirme düzeyleri açısından farklılık yoktur.

Eşler kadınların girişimci faaliyetine engel mi olur? Güçlü ataerkil toplumsal yapının geçerli olduğu toplumlarda bu sorunun cevabının eşlerin kadınlara girişimcilik faaliyetlerinde engel olacağı yönünde olduğu düşünülebilir. Zira kadının çalışma hayatına dahil olmasıyla ilgili güçlü kalıpyargılar bulunmaktadır. Ancak uygulamalı çalışmalar ve kadın girişimciliği konusundaki yazın aksini söylemektedir. Araştırma sonuçları diğer uygulamalı çalışmaları ve ilgili yazını destekleyen bulgular elde etmiştir. Araştırma kapsamında görüşülen kadın girişimciler, anketlerin uygulanması sırasında, işletmenin kurulması ve yönetilmesi sürecinde karşılaşılan problemlerin sorulduğu sorularda, eşlerinin kendilerine yardım ettiğini sözel olarak ifade etmiştir. Eşlerin girişimcilik faaliyetine bilgi, tecrübe ve network paylaşımı şeklinde sağladıkları bu destek, yazın ile paraleldir (Liao ve Stevens, 1994; Bernardi, 1999; Özcan, 2011: 6-7; Orwa, Tiagha ve Waiguchu, 2014: 210). Bekâr girişimciler ise aynı desteği ebeveynlerinden almaktadır. Bu sonuç Baruah'ın (2010) Hindistan’da gerçekleştirdiği çalışma sonuçlarını desteklemektedir. Evli ve bekâr girişimcilerin işletmenin kurulması, yönetilmesi ve işletmenin kurulmasından sonraki süreçte karşılaştıkları sorunlar, tüm bu süreçlerde aile ve yakın çevreden olumsuz baskı hissetme düzeyi, yakın çevreden destek olanların sayısı benzerdir; iki grup arasında istatistiksel olarak anlamlı bir farklılık bulunmamaktadır.

Uygulamalı çalışmalar incelendiğinde Türkiye'de kadın girişimciliği konusunda ilgili yazında hala büyük boşluklar olduğu görülmektedir. Yerel ve bölgesel düzeyde kadın girişimcilerin mevcut durumunu ve sorunlarını toplumsal cinsiyet rolleri çerçevesi içinde irdeleyen çalışmalar şüphesiz kadın girişimciliğinin desteklenmesi çabalarına olumlu katkıda bulunmaktadır. Diğer yandan kadın girişimcilerin Türkiye'deki gelişimiyle paralel olarak uygulamalı çalışmalarda konunun irdelenme şekli de değişik göstermektedir. Yakın zamanda kadın girişimcilerin çalışma hayatına odaklanan uygulamalı çalışmalarda artış gözlenmektedir. Kadın girişimcilerin iş-yaşam dengesi, işletmecilik bilgi ve becerileri gibi konular daha çok araştırılmaktadır. Ancak yine de kadın girişimcilerin çalışma hayatını irdeleyen araştırma sayısı kısıtlıdır. Çalışma hayatı içinde spesifik olarak kadın girişimcilere odaklanan yeni ve farklı konularda çalışmalara ihtiyaç bulunmaktadır.

Yeni bir girişim kurmak tüm girişimciler için zorlu süreçler içerir. Bu zorlu süreçler içinde ayakta kalmaya ve başarılı olmaya çalışan kadın girişimciler, aynı zamanda toplumsal cinsiyet rollerinden ve kalıpyargılardan beslenen sorunlar ile mücadele etmektedir. Bu bağlamda kadın girişimcileri konu alan yeni çalışma konuları önerilebilir. Örneğin, tükenmişlik düzeyi. Tükenmişlik, günümüzün stresli iş hayatında sık rastlanan bir durumdur ve bireyin zihinsel, fiziksel ve duygusal olarak tükenmesini ifade eder. Tükenmişliğin sonuncunda kişisel başarısızlık hissi, duygusal bitkinlik, yoğunlaşma eksikliği gibi sorunlar görülebilmektedir (Yıldırım, 2018: 303). Acaba yeni girişim sahibi kadınların tükenmişlik düzeyi nasıldır, faaliyette bulunulan sektöre, medeni duruma, çocuk sayısına, işletmenin büyüklügüune ve yaşına göre farklılık göstermekte midir? Güçlü ataerkil toplumsal yapının geçerli olduğu bölgelerde yaşayan kadın girişimcilerin tükenmişlik düzeyinin nasıl olması beklenebilir? Araştırılması önerilebilecek bir diğer konu sinizm olarak düşünülebilir. Örgütsel sinizm bireyin çalıştığı örgüte yönelik olarak geliştirdiği bilişsel, duygusal ve davranışsal boyutları içeren negatif bir tutumdur (Görmen, 2017: 366). Yaşama ilişkin olumsuz tutum ve duygular taşıyan birey zamanla sinik bir birey haline gelmektedir (Yıldırım ve Yıldırım, 2016). İş yaşam dengesini sağlamaya çalışan kadın girişimciler, zaman içinde girişimlerine karşı nasıl bir duygu durum içine girmektedir, hangi faktörler onların bu tutumlarını etkilemektedir? Spesifik olarak kadın girişimcileri konu alan, bu ve benzeri konuların araştırılması, çalışma hayatında kadın girişimcilerin farklı yönleriyle daha iyi anlaşılmasına katkıda bulunacaktır.

Türkiye'de sosyal girişimci kadınlara odaklanan çalışma sayısı kısıtlıdır (Cicek ve Türkmenoğlu, 2018: 54). Özellikle dezavantajlı bölgelerde yaşayan kadınlara odaklanan sosyal girişimci kadınların faaliyetlerinin araştırılması, başarı hikayelerinin ulusal ve bölgesel düzeyde toplumla daha çok paylaşılması kadın girişimciliğinin gelişmesine ve bu konudaki kalıpyargıların azaltılmasına katkıda bulunacaktır. 


\section{Kaynakça}

Adegbite, S.A., Ilori, M.O., Irefin, I.A., Abereijo, I.O., \& Aderemi, H.O.S. (2006). Evaluation of the impact of entrepreneurial characteristics on the performance of small scale manufacturing industries in Nigeria. Journal of Asia Entrepreneurship and Sustainability, 3(1), 113-135.

Aderemi, H. O. (2008). An assessment of the choice and performance of women entrepreneurs in technological and non-technological enterprises in south-western Nigeria. African Journal of Business Management, 2(10), 165-176.

Adewale, A. A. (2016). Effect of demographic factors on entrepreneurial culture: a study of university students in metropolitan Kano. American Journal of Social Sciences and Humanities, 1(1). 10-34. http://dx.doi.org/10.20448/journal.801/2016.1.1/801.1.10. 34

Aghajani, H., \& Abbasgholipour, M. (2012). Explanation of relationships between biographical characteristics and entrepreneurship spirit of students. Iranian Journal of Management Studies, 5(1), 63-78.

Akgül Koç, S., \& Siklon, S. (2009). Depremde kadının özel alandan kamusal alana geçiş süreci ve sivil toplum kuruluşları.İçinde: Uluslararası-Disiplinlerarası Kadın Çalışmaları Kongresi Bildiriler Kitabı, 05-09 Mart 2009, Sakarya. 265-279.

Altuntaş, H. T. (2016). Girişimcilik destek programlarının aktif istihdam politikası üzerindeki etkinliği: KOSGEB yeni girişimcilik programı örneği ve TR21 analizi. Balkan ve Yakın Doğu Sosyal Bilimler Dergisi, 2(4), 35-42.

Ankara Kalkınma Ajansı (2014). Ankara'da Kadın Girişimciliği: Örnekler ve Yol Haritası. Kadın Girişimciliği ve Girişimci Ekosistemi Araştırmalar Serisi 2.

Ballı, A. İ. (2017). Kadınların girişimci olma nedenleri ve önlerindeki engeller: kadın girişimci adayları üzerine uygulamalı bir araştırma. Organizasyon ve Yönetim Bilimleri Dergisi, 9(1), 42-63.

Baruah, H.K. (2010). Problems of woman entrepreneurs in a tribal area a study of Udalguri district of BTAD, Assam. Doktora Tezi. Hindistan: Gauhati University.

Batı, B. G., \& İnel, M. N. (2015). Kadın Girişimcilerin profíli bağlamında çatışma düzeyleri ve yatırım tercihleri: Yalova ili üzerine inceleme. Marmara Üniversitesi Öneri Dergisi, 11(44), 101-119.

Becker, G. S. (1973). A Theory of Marriage: Part I. Journal of Political Economy, 81(4), 813-846.

Berglann, H., Moen, E.R., Røed, K. ve Skogstrøm, J.F. (2010). Entrepreneurship: origins and returns. CREAM Publication No. 7. Center For Research in Economics and Management, Norvegian School of Management.

Bernardi, F. (1999). Does the husband matter? Married women and employment in Italy. European Sociological Review, 15, 285-300.

Bingöl, G., \& Türkmen, Y. S. (2016). Girişimciliğin finansmanında melek sermaye ve Türkiye uygulaması.
Marmara Üniversitesi Öneri Dergisi, 12(45). 357-373. http://dx.doi.org/10.14783/od.v12i45.1000020017.

Bose, V. (2012). An analytical study of the impact of women entrepreneurship development measures promoted by the Government and Financial Institutions in Kerala. Doktora Tezi. Hindistan: Mahatma Gandhi University.

Boyacığlu, E. Z. (2014). Kırsal turizmde kadın girişimciliği: Edirne örneği. Uluslararası Sosyal ve Ekonomik Bilimler Dergisi, 4(2). 82-90.

Brush, C., de Bruin, A., \& Welter, F. (2009). A gender-aware framework for women's entrepreneurship. International Journal of Gender and Entrepreneurship, 1(1), 8-24.

Cicek, B., \& Türkmenoğlu, M.A. (2018). Women as Social Entrepreneurs in Turkey. In: D. Chitakunye, \& A. Takhar (Eds.), Examining the Role of Women Entrepreneurs in Emerging Economies (53-74). Pennsylvania, ABD: IGI Global. http://dx.doi.org/10.4018/978-1-5225-51126.ch003

Çetinoğlu, T., \& Büber, R. (2012). Ostim organize sanayi bölgesinde girişimcilik açısından kültür ve kişilik özelliklerinin analizine yönelik bir alan araştırması. Dumlupınar Üniversitesi Sosyal Bilimler Dergisi, 33, 193210.

DeMartino, R., \& Barbato, R. (2003). Differences between women and men mba entrepreneurs: exploring family flexibility and wealth creation as career motivators. Journal of Business Venturing, 18(6), 815-32. http://dx.doi.org/10.1016/S0883-9026(03)00003-X

Durmuş, B., Yurtkoru, E.S., \& Çinko, M. (2013). Sosyal Bilimlerde SPSS'le Veri Analizi. (5. Baskı). İstanbul: Beta Yayınevi.

Erdoğan, E. (2017). Türkiye'de Gençlerin Iyi Olma Hali Saha Araştırması Bulguları. Habitat Derneği Yayını.

Erdun, Ș. (2011). Kadın Girișimcilerin Risk Alma Eğilimi Ve Kendine Güven Özellikleri Üzerine Bir Çalışma: Zonguldak Örneği. Yüksek Lisans Tezi. Zonguldak: Zonguldak Kara Elmas Üniversitesi.

Fielden, S.L., Davidson, M.J., \& Makin, P.J. (2000). Barriers encountered during micro and small business start-up in North West England. Journal of Small Business and Enterprise Development, 7(4), 295-304.

Genç, K.Y. (2015). Girişimcilik kurslarına katılanların temel eğilimleri üzerine bir araştırma. İşletme Fakültesi Dergisi, 16 (2), 155-175.

Goffee, R., \& Scase, R. (1992). Kadınlar iş başında. (Çev. A. Fethi). İstanbul: Eti Kitapları.

Görmen, M. (2017). Örgüt kültürünün örgütsel sinizm tutumları üzerine etkisi. Bartın Üniversitesi IIBF Dergisi, 8(15), 363-387.

Gürer, A., \& Çiftçi, G. E. (2018). Kültürel zekanın bireysel girişimcilik yönelimi üzerindeki etkisi. İçinde: Al-Farabi 2nd International Congress on Social Sciences. 6-8 Nisan, Gaziantep, 490-518.

İnce, A.R., Çamlıbel, F., \& Birol, E. (2016). Kosgeb girişimcilik eğitimine katılan kursiyerlerin girişimcilik kararını etkileyen sebepler üzerine bir araştırma. Süleyman 
Demirel Üniversitesi İktisadi ve İdari Bilimler Fakültesi Dergisi, 21(1), 113-123.

Kahya, C., \& İmamoğlu, İ.K. (2013). Sosyo-demografik özellikler ve girişimcilik ilişkisinin yerel kalkınma bağlamında değerlendirilmesi (Bayburt ili örneği). Akademik Bakış Dergisi, 38, 4-14.

Kalaycı, Ş. (2017). SPSS Uygulamalı Çok Değişkenli İstatistik Teknikleri. (8. Baskı) Ankara: Dinamik Akademi.

Kutukız, D., \& Özden, C. (2018). Kadın girişimciliği ve finansal okuryazarlığın kadın girişimciler üzerindeki etkisi. Uluslararası Toplum Araştırmaları Dergisi, 8(8), 349-365.

Latif, A., Begum, S., \& Lubna R.J. (2015). Perceptions about effect of family related factors on women entrepreneurship: a study on existing and intended women entrepreneurs of Sylhet city, Bangladesh. International Journal of Advances in Management and Economics, 4(4), 104-112.

Liao T.F., \& Stevens, G. (1994). Spouses, homogamy and social networks. Social Forces, 73, 693- 707.

Moutray, C. (2007). Educational Attainment and Other Characteristics of the Self-Employed: An Examination Using Data from the Panel Study of Income Dynamics. Research Report. U.S. Small Business Administration, Office of Advocacy. December 2007.

Najimudinova, S. (2015). Kırgızistan'da kadın girişimciliği: durum analizi ve perspektifleri. Sosyoekonomi Dergisi, 23(24), 7-22.

Olowa, O.W., \& Olowa, O.A. (2015). Factors affecting entrepreneurship development in agribusiness enterprises in Lagos State, Nigeria. Global Journal of Management and Business Research: B Economics and Commerce, 15(7), 25-32.

Orhan, K. (2017). Girişimci kaderini yener mi: girişimci eğilime kaderciliğin etkisi. Uluslararası Yönetim İktisat ve Işletme Dergisi Özel Sayısı, 143-159.

Orwa, B.H., Tiagha, E., \& Waiguchu, M. (2014). An empirical analysis of entrepreneurship scorecard and performance of small scale women entrepreneurs in urban- Kenya. International Journal of Humanities and Social Science, 4(5), 208-215.

Ödemiş, G. (2018). Kadın Girişimcilerin İş-Yaşam Dengesi Üzerine Bir Araştırma: İzmir İli Örneği. Yüksek Lisans Tezi. İzmir: Kâtip Çelebi Üniversitesi.

Özcan, B. (2011). Only the lonely?: the influence of spouse on the transition to self- employment. Small Business Economics, 37(4), 465-492.

Özçatal, Ö. (2009). Kadınların işgücü piyasasına katılımını ve çalışma koşullarını etkileyen sosyo-demografik ve kültürel faktörler. İçinde: Uluslararası- Disiplinlerarası Kadın Çalışmaları Kongresi Bildiriler Kitabı, 05-09 Mart 2009, Sakarya. 45-54.

Özyılmaz, A. M. (2016). Türkiye'de Kadın Girişimciliği ve Girişimci Kadınların Karşılaştıkları Sorunlar Üzerine Bir Araştırma. Yüksek Lisans Tezi. Nevşehir: Nevşehir Hacı Bektaş Veli Üniversitesi.
Peter, P.W., \& Munyithya, H.M. (2015). The gender factor influence on entrepreneurial success in Kitui County, Kenya. International Journal of Education and Research, 3(7), 13-32.

Reynolds, P. (1999). Nascent Entrepreneurship in Northern Europe, in EIM (Ed.). Entrepreneurship in the Netherlands. (The Hague/Zoetermeer:EIM/EZ)

Survey System (2017). Sample Size Calculator. (Erişim Tarihi: $\quad 1$ Nisan 2017), https://www.surveysystem.com/sscalc.htm

Şahin E. (2006). Kadın Girişimcilik ve Konya İlinde Kadın Girişimcilik Profili Üzerine Bir Uygulama. Yüksek Lisans Tezi. Konya: Selçuk Üniversitesi.

Tamizharasi G., \& Panchanatham, N. (2010). An empirical study of demographic variables on entrepreneurial attitudes. International Journal of Trade, Economics and Finance, 1(2), 215-220.

Thompson, E., Asarta, C., Zhang, Z., \& LeMarie, F. (2013). The Role of Parental Experience in Entrepreneurship Choice among Adults. Bureau of Business Research Publications. University of Nebraska, Lincoln, ABD.

Tulan, D., \& Türko, E. S. (2018). Kadın girişimciliği: Erzurum ilinde bir uygulama. Finans Ekonomi ve Sosyal Araştırmalar Dergisi, 3(1), 285-306.

Türko, E. S. (2016a). Business plan vs business model canvas in entrepreneurship trainings, a comparison of students' perceptions. Asian Social Science, 12(10). 55-62. http://dx.doi.org/10.5539/ass.v12n10p55

Türko, E. S. (2016b). Can entrepreneurship education reduce stereotypes against women entrepreneurship?. International Education Studies, 9(11). 53-65. http://dx.doi.org/10.5539/ies.v9n11p53

Uluköy, M., \& Bayraktaroğlu, S. (2014). A field research about oppression incurred of woman entrepreneurs in patriarchal societies. Yönetim ve Ekonomi Araştırmalar Dergisi, 24, 356-369. http://dx.doi.org/10.11611/JMER507

Yıldırım, F. (2018). Tükenmişlik düzeyinin sanal kaytarma davranışına etkisinde iş doyumunun aracılık rolü. Gazi Üniversitesi Sosyal Bilimler Dergisi, 5(13), 302-313.

Yildırım, F., \& Yıldırım, S.K. (2016). Effects of cynicism on empowerment in organizations. Journal of Human Sciences, $\quad 13(3), \quad 5740-5750$. https://doi.org/10.14687/jhs.v13i3.4124 